\title{
GEDIMINAIČIỤ DINASTIJOS VAIDMUO ORGANIZUOJANT KARO VEIKSMUS LIETUVOS DIDŽIOJOJE KUNIGAIKŠTYSTĖJE XIV A.
}

\author{
Vytas Jankauskas \\ Vytauto Didžiojo universitetas
}

\section{IVADAS}

Siekiant geriau nušviesti Lietuvos Didžiosios Kunigaikštystès raidą nuo XIII a. pabaigos iki XV a., labai svarbu deramą dėmesị skirti dinastijos istorijai ir hierarchiniams santykiams. Ši problema daugialypé, nes aptariamojo laikotarpio šaltiniuose dažniausiai randama tik užuominų ir netiesioginių duomenų. Dèl to bandyti aiškintis, kokie buvo dinastijos narių santykiai struktūros viduje, dar sunkiau. Šiame darbe mèginama įvertinti dinastijos, kaip struktūros, poveikị XIII a. pab.-XIV a. rengiant karo veiksmus.

Edvardas Gudavičius, rašydamas apie ankstyvosios karinès demokratijos modeli, pabrèžè, kad rasti demokratijos apraiškų lietuvių kariaunose gana sunku. Taip pat tyrejjas ironiškai kalba ir apie iš plěšikavimo gyvenančią valstybę, tačiau nemenkina kariaunų vaidmens jos plètros procese ${ }^{1}$. Istoriografinè polemika, atrodo, yra ịstrigusi aklavietejje, iš kurios galètų išvesti tik papildomos žinios - nauji šaltiniai. Vis dèlto dèsningumai akivaizdžiai matyti stebint karo žygių intensyvumą ${ }^{2}$. Lietuvos istoriografijoje Vytenio valdymo metai pripažinti kaip kokybinių pokyčių LDK karyboje laikotarpis. Teigiama, kad šis valdovas gali būti vadinamas paskutiniu Lietuvos vikingu ${ }^{3}$. Tuo metu stiprèjo lietuvių kavalerija, atsirado nuolatinių kariaunų, keitėsi valdovo vaidmuo kariuomeneje ir t. t. ${ }^{4}$ Tiesa, požymiai, pagal kuriuos sprendžiama apie šiuos pokyčius, nèra vien tik kalbamojo laikotarpio ypatumai, tačiau jie byloja apie ilgiau trunkančius procesus, todèl kalbèti apie aiškesnius

1 Gudavičius E., Mindaugas, Vilnius, 1998, p. 98.

2 Baranauskas T., Lietuvos valstybès ištakos, Vilnius, 2000, p. 172-178.

3 Gudavičius E., Lietuvos istorija: Nuo seniausių laikų iki 1569 metų, T. 1, Vilnius, 2000, p. 83.

4 Nikžentaitis A., Nuo Daumanto iki Gedimino. Ikikrikščioniškos Lietuvos visuomenès bruožai // Acta historica Universitatis Klaipedensis, T. 5, Klaipėda, 1996, p. 44-45. 
pasikeitimus ir struktūras veikiausiai yra per drąsu, juolab kad šaltiniotyros problemos kartais virsta bandymais atsakyti ị labai svarbius klausimus 5 .

Lietuvos istoriografijoje Gediminaičių dinastijos vaidmuo organizuojant karo veiksmus XIV-XV a. pradžioje nèra deramai įvertintas. Negalima teigti, jog istorikai šio klausimo vengia. Veikiau sakytume, kad ją užgožia kitos problemos. Dėl to turime daugybę darbų, kuriuose galima rasti vienokių ar kitokių pastabų mus dominančia tema, tačiau neiškeliančių pačios problemos. Vienintelis specialus tyrimas, kuriame konkrečiai kalbama apie Gediminaičius vienos karo kampanijos metu, - Romo Batūros darbas, skirtas Kulikovo mūšio vadams ${ }^{6}$, tačiau ir ji panaudoti nèra paprasta, kadangi jame rašoma ne apie LDK vykusius procesus, o apie Maskvos didžiąą kunigaikštystę. XIV a. LDK mūšiu istorija taip pat nèra deramai ịvertinta. XIII a. didžiosios kautynès sulaukẻ savų tyrèjų, o XIV a. vykę kariniai susidūrimai liko nuošalyje. Išimtimi laikytinas Mėlynujų Vandenų mūšis, kuriuo pakankamai domėtasi. Lietuvos istoriografijoje išskirtinas ir R. Batūros darbas kovoms su Aukso orda aptarti, kuriame Mèlynųjų Vandenų mūšiui skiriama daug dèmesio. Ji galima laikyti atskira studija 7 . Siam klausimui daug dėmesio skyrè ir ukrainiečiai istorikai ${ }^{8}$, tačiau dinastija ir organizaciniai aspektai liko nuošalyje. Vis dèlto būtina pridurti, jog Lietuvos Didžiosios Kunigaikštystès karo veiksmų organizavimo ir Gediminaičių dinastijos narių vaidmens šiame procese klausimai nèra visiškai dingęs iš istoriografijos. Tokių studijų yra, tačiau mus dominančiais aspektais jos gana fragmentiškos, kartais paremtos daugiau stereotipais, negu realiu požiūriu ị šaltinius. Vienas tokių stereotipų darnus Algirdo ir Kęstučio valdymas, jiems pasiskirsčius politines ir karines

5 Plg.: ten pat, p. 46. Šiuo atveju kalbama apie tendenciją įtraukti rutenus (tekste - rusus) į LDK puolimus vakaruose. Kyla klausimas, ar tai, kad iki XIV a. vidurio rutėnai nėra dažnai minimi, yra šaltiniotyros problema, ar rutėnų integracijos padariniai? Pirmuoju atveju sugriūva visa struktūra.

6 Batūra R., Lietuvos karo vadai ir kariai 1380 m. Kulikovo mūšyje // Karo archyvas, T. 19, Vilnius, 2004, p. 84-147.

7 Batūra R., Lietuva tautų kovoje prieš Aukso Ordą: Nuo Batu antplūdžio iki mūšio prie Mélynųjų Vandenu, Vilnius, 1975, p. 173-310.

8 Синьоводська проблема у новітніх дослідженнях: Збірник статей, Київ, 2005; Шабульдо Ф. М., Битва біля Синіх Вод 1362 р.: маловідомі та незнані аспекти // Український історичний журнал, 1996, Но. 2, с. 3 - 15; Шабульдо Ф. М., Синьоводська проблема: можливий спосіб ї̈ розв'язання. Історичні зошити, Київ, 1998; Ващук Д. П. Проблема входження Поділля до складу Великого князівства Литовського в другій половині XIV cm.: історіографічний аспект // Кам'янець-Подільський у контексті українсько-європейських зв'язків: історія і сучасність: Збірник наукових праць за підсумками міжнародної науковопрактичної конференції, Кам'янець-Подільський, 2004, с. 40-42. 
kryptis $^{9}$, kartu kalbama ir apie brolišką pagalbą rengiant žygius ${ }^{10}$. Kai kurie istorikai čia įžvelgia diarchijos požymių, tačiau tai jau kitas klausimas ${ }^{11}$.

Visa tai verčia ieškoti atsakymo ị klausimą - kaip funkcionavo dinastija rengiant karo veiksmus. I ji atsakyti gana sunku, todèl tenka grižži prie tụ pačių istoriografijoje gerai žinomų šaltiniu - metraščių, kronikų, aktų - ir bandyti juos skaityti dar kartą.

\section{„SAUSUMOS VIKINGÜ“ LAIKOTARPIO PABAIGA}

Žinių apie Gediminaičiu giminès narius, gyvenusius iki Gedimino valdymo pradžios, nèra labai daug. Šiai giminei priskiriamas Butigeidis, Butvydas (Pukuveras) ir Vytenis, kurie turejo būti valdovai, taip pat Vytenio sūnus Žvelgaitis. Apie Gediminaičiu protèvị Skalmantą sužinome iš vèlyvo šaltinio, kur jis nurodomas kaip Andriaus ir Dimitrijaus Algirdaičių prosenelis, tačiau apie jo veiklą XIII a. nieko nerasta ${ }^{12}$. Veikiausiai šiai giminei taip pat priklausė ir kunigaikštis, minimas Petro Dusburgiečio kronikoje, kalbant apie Pelužio išdavystę $^{13}$. Gediminas suteikè vardą visai dinastijai. Todèl apie šios giminès narius, žinomus iki Gedimino, kalbèti kaip apie Gediminaičius ne taip lengva. Vis dèlto giminèje vykę procesai negalëjo nepaveikti vèlesnių dinastijos funkcionavimo ir hierarchizavimo procesų, todèl jų ignoruoti taip pat negalima. Tas pat pasakytina ir diskutuojant karo veiksmų organizavimo klausimais. Kadangi kalbant apie XIII-XIV a. sandūrą iškyla labai reikšminga šaltiniu problema, Lietuvos Didžiosios Kunigaikštystès kuriamas vaizdas gana neaiškus.

Alvydas Nikžentaitis - vienas iš nedaugelio istorikų, bandžiusių apibrèžti kariuomenès vado padèties pokyčius XIII-XIV a. sandūroje. Pasak jo, jau XIII a. antrojoje pusèje valdovo ir kariuomenès vado funkcijos pradèjo išsiskirti. Šiam teiginiui iliustruoti jis pasitelkia Traidenio, kuris rèmèsi savo broliu Sirpučiu ir žiemgaliu Nemeisiu, pavyzdi ${ }^{14}$ Negalima svarstyti, jog valstybès susidarymas nepadare įtakos funkcijų atsiskyrimo procesui, tačiau šio reiškinio užuomazgu matyti jau Mindaugo, kuris karo veiksmuose taip pat vengè daly-

9 Plg.: Kučinskas A., Kęstutis, Vilnius, 1988, p. 198-201.

10 Ten pat, p. 200-202.

11 Гудавичюс Э., По поводу так называемой диархии в Великом Кнежестве Литовском // Feodālisms Baltijas regionā, Rīga, 1985, c. 35-44.

12 Ochmański J. Dawna Litwa. Studia historyczne, Olsztyn, 1968, s. 19-24.

13 Petri de Dusburg, Chronicon terrae Prussiae, ed. M. Töppen // Scriptores rerum Prussicarum: Die Geschichtsquellen der preussischen, Bd. 1, Leipzig, 1861, s. 149.

14 Nikžentaitis A., Nuo Daumanto iki Gedimino. Ikikrikščioniškos Lietuvos visuomenès bruožai // Acta historica Universitatis Klaipedensis, T. 5, Klaipėda, 1996, p. 45. 
vauti ir garsejo kaip ne itin sėkmingas karvedys, valdomoje Lietuvoje $\mathrm{e}^{15}$. Todèl galètume atkreipti demesį net kelis atvejus, kai jis kariuomenei vadovauti pavedè savo giminaičiams ar aplinkos žmonèms. Todèl XIII-XIV a. sandūroje toks valdovo, kaip kariuomenès vado, aktyvumas atrodo gana keistas. Vis dèlto suabsoliutinti šio klausimo nederètu. Tas pats Traidenis nevengè dalyvauti karo žygiuose, po jo valdęs kunigaikštis Domantas (Daumantas) taip pat buvo aktyvus, kol galiausiai žuvo prie Tverès 1285 metais ${ }^{16}$. Todèl įžvelgti šio laikotarpio valdovo ir vado funkcijų santykio didesnius pokyčius ganėtinai sunku. Kalbant apie pirmuosius Gedimino giminès valdymo metus daugiau būtų galima pasakyti analizuojant konkrečią mums prieinamų šaltinių informaciją.

Pirmieji didieji šios giminès kunigaikščiai nerodè didelès iniciatyvos dalyvaudami karo veiksmuose. Pirmą kartą Butigeidis ir Butvydas minimi 1288 m., kai suteikė teritorinių nuolaidų Voluinei ${ }^{17}$. Neaišku, kokiomis aplinkybėmis tai îvyko, tačiau teritorinès nuolaidos nedaromos šiaip sau. Tam turejjo būti priežasčių. $1290 \mathrm{~m}$. Butigeidis dar kartą buvo paminètas Livonijos krašto magistro laiške ị Prūsiją, kuriame jis rašo, kad puls karaliaus Butigeidžio žemes ${ }^{18}$. Tokiu atveju šis kunigaikštis organizuojant karo veiksmus vėl lieka nuošalyje. Tačiau yra dar viena išlyga. $1289 \mathrm{~m}$. Petras Dusburgietis aprašè anoniminio „Lietuvos karaliaus“ ir jo 8000 vyrų žygị i Sembą ${ }^{19}$. Neaišku, ar tai tikrai buvo Butigeidis. Labiausiai dèl anonimiškumo. Galbūt karaliumi vadinamas didžiojo kunigaikščio brolis ar sūnus, tačiau tas asmuo galejo būti ir pats valdovas. Dèl kai kurių galimybių galima suabejoti, nes kronikininkas žinojo brolio, kaip ir sūnėno, vardą. Taigi didelè tikimybè, kad žygiui vadovavo pats Butigeidis, dingęs iš istorijos šaltinių po kelerių metų (veikiausiai miręs sava mirtimi, nes sostą perémé jo brolis). Taigi akivaizdu, kad XIII a. pabaigoje valdovo vaidmuo ir dalyvavimas organizuojant karo žygius buvo labai svarbus.

Butvydo (Pukuvero) problema gana seniai aptarta ${ }^{20}$ ir dèl jos naujausioje istoriografijoje beveik nekyla klausimų ${ }^{21}$. Pirmą kartą jis su broliu Butigeidžiu

15 Baranauskas T., Lietuvos valstybès ištakos, Vilnius, 2000, p. 208-209.

16 Dubonis A., Traidenis: Monarcho valdžios atkūrimas Lietuvoje 1268-1282, Vilnius, 2009, p. 71-79.

17 Полное собрание русских летописей, Т. 2: Ипатьевская летопись, СПб, 1843, с. 225.

18 Preußisches Urkundenbuch, Bd. 1, Hälfte 2, ed. A. Seraphim. Königsberg, 1909, Nr. 568, p. 355-356.

19 Petri de Dusburg, Chronicon terrae Prussiae, ed. M. Töppen // Scriptores rerum Prussicarum: Die Geschichtsquellen der preussischen, Bd. 1, Leipzig, 1861, s. 151-152.

20 Puzyna J., Kim byt i jak sie naprawde nazywat Pukuwer ojciec Giedymina // Ateneum Wileńskie, T. 10, 1935, s. 18-19.

21 Гудавичюс Э., По поводутак называемой диархии в Великом Кнежестве Литовском // Feodālisms Baltijas regionā, Rīga, 1985, c. 36-37. 
minimi, kai 1289 m. dalyvavo sprendžiant konfliktą su Voluine. Vèliau mes jị matome kaip pasyvų valdovą: $1292 \mathrm{~m}$. Lietuvos karaliaus Pukuvero sūnus Vytenis įsiveržè ị Kujavijos Brestą ${ }^{22}, 1294$ m. „Lietuvos karaliaus sūnus“ Vytenis užèmé Lenčicąa ${ }^{23} .1296$ m. Vytenis jau ịvardijamas Lietuvos karaliumi ${ }^{24}$.

Istoriografijoje apie Butigeidị ir Butvydą nieko nerašoma apie smurtinị valdžios perėmimą. Kalbama apie funkcionavusią nuoseklią sistemą, kuri keičiantis valdovams užtikrino sklandų valdžios perdavimąa ${ }^{25}$. Tačiau tai neturi didelès reikšmès. Svarbiausia, kad per kelerius metus savo mirtimi mirè du broliai. Tai daug ką sako apie šios kartos, išeinančios iš istorijos arenos, situaciją, iškalbingai paaiškina, kodèl jie taip pasyviai elgèsi, kai reikèjo organizuoti karo veiksmus. $1289 \mathrm{~m}$. Butigeidžio žygi reikètų laikyti išimtimi. Taip pat negalima pamiršti ir to, kad jeigu Butigeidis ir Butvydas XIII a. devintojo dešimtmečio viduryje būtų sulaukę senatvès, veikiausiai nebūtų galejję ịsitvirtinti valdžioje. Taigi akivaizdu, kad šie valdovai kaip karo vadai buvo pasyvūs. Butigeidžio aktyvumą galima būtų palyginti su Daumanto aktyvumu iki pat jo mirties, tačiau turètume prisiminti ir E. Gudavičiaus pasvarstymus dèl pastarojo amžiaus, tačiau su tam tikra išlyga, nes žinome, kad Daumantas mirè per epidemiją ${ }^{26}$.

Vis dèlto negalima tvirtinti, kad Butigeidžio ir Butvydo kartai karo veiksmai ir jų organizavimas buvo antraeiliai dalykai. Jų valdymo metu buvo tvirtinamas pasienis su Vokiečių ordinu (plg. Junigedos - Veliuonos pilies statyba). Taip pasyviai laukta karo veiksmų, tačiau ir tai buvo svarbu, siekiant išlaikyti teritorijos vientisumą ir apsaugoti valstybę. Be to, tuo metu funkcionavo gynybinès pilių sistemos, kurios dažniausiai padėdavo. Tačiau Butvydo pozicija, nors jis ir nedalyvaudavo karo veiksmuose, šiuo aspektu buvo aktyvi. $1292 \mathrm{~m}$. būtent jis pasiunté savo sūnų kariauti ị Lenkiją. Taigi, vis dèlto rūpinosi karo veiksmų organizavimu. Vadovauti pajègoms buvo pavesta sūnui. Kiek kitaip atrodo kitas Vytenio žygis, surengtas dar Butvydui gyvam esant. Neaišku, ar jis vyko Butvydui žinant, ar ne, tačiau šis žygis buvo mažesnis ir jo tikslai buvo gerokai siauresni. Taip pat, jeigu palygintume Butigeidžio žygio ị Sembą pajègas su Vytenio žygio ị Lenčicą pajègomis, akivaizdu, kad jos skiriasi dešimti kartų. Dėl to pastarasis labiau primena XIII a. pirmosios pusės kunigaikščių

\footnotetext{
22 Petri de Dusburg, Chronicon terrae Prussiae, ed. M. Töppen // Scriptores rerum Prussicarum: Die Geschichtsquellen der preussischen, Bd. 1, Leipzig, 1861, s. 155-156.

23 Ten pat, p. 156-157.

24 Ten pat, p. 163.

25 Plg.: Nikžentaitis A., Gediminas, Vilnius, 1989, p. 8-11.

26 Gudavičius E., Mindaugas, Vilnius, 1998, p. 149-150.
} 
plëšiamuosius žygius ${ }^{27}$, o ne valstybès politinių tikslų igyvendinimo kampaniją. Peršasi mintis, jog Vytenis ị $1294 \mathrm{~m}$. žygị išvyko pasitelkęs asmeninę kariauną, o ne valstybės pajëgas ir veiké savo iniciatyva. Reikètų pridurti, jog šios pajègos buvo gana didelès, kas liudija Vytenio reikšmę dinastijos struktūroje. Šiame kontekste būtina paminèti ir pirmuosius Vytauto žygius, kuriuos jis atliko savarankiškai ir su gerokai mažesnèmis pajėgomis ${ }^{28}$.

Dar vienas akivaizdus šio laikotarpio lietuvių, kartu ir dinastijos narių, karybos bruožas, nesusijęs su politinių valstybès interesų iggyvendinimo būdais, buvo paplitęs kraujo kerštas, kurio apraiškų įžvelgiame XIII a. pirmojoje pusė$\mathrm{je}^{29}$. Tai iliustruojama ne itin patikimais pavyzdžiais, tačiau jų nepaisyti taip pat negalima. Istorikai sutaria, jog aukščiausią padètị valstybẻje po valdovo užèmé dinastijos nariai, pirmiausia - artimiausi giminaičiai. Tuo remiantis galima gretinti du Petro Dusburgiečio aprašymus. Pirmasis, susijęs su Pelužio išdavyste, rašytas 1286-1288 m., tačiau tiksliai nedatuotas. Kitas epizodas sietinas veikiausiai su Butigeidžio įsiveržimu ị Sembą 1289 metais. Tarp jų įsiterpè pasakojimai apie kelių ordino brolių, naujo Prūsijos žemès magistro išrinkimą, Ragainès ir Skalviu pilių pastatymą. Todèl šis pasakojimas, išmetus intarpus, gali pasirodyti gana išsamus: Pelužis pabėgo į Sembą, kur ieškojo paramos, nes jị buvo ịžeidęs „nelyginant antrasis asmuo po Lietuvos karaliaus“. Pelužis paramą gavo Karaliaučiuje, grịžo ị Lietuvą ir užpuolè nusigèrusius kunigaikščio svečius, kurie puotavo jo pilyje. Pilies savininką ir daugybę svečių nužude, paėmé belaisvių ir apiplèšęs pili pasitraukè. Lietuvos karalius (veikiausiai Butigeidis) su 8000 raitelių įsiverže į Sembą ir per 14 dienų plěšdamas peržygiavo šią žemę ${ }^{30}$. Šiuo požiūriu pasakojimas yra išbaigtas ir nuoseklus, tačiau lakoniškas, nes apie Butigeidžio ịsiveržimą pateikiama nedaug žinių. Nerašoma, kaip didvyriškai broliai gynèsi, tik nurodoma, jog buvo nukauta 80 lietuvių (vis dèlto susidūrimų būta). Atrodo, žygis turèjo labai konkretų tikslą, nes nebuvo nei daug „krikščionių“ nužudyta, nei padaryta daug žalos plèšiant. O surinktos kariuomenės mastas ispūdingas. Veikiausiai Vokiečių ordino pasirinktas gynybos būdas nebuvo pats

\footnotetext{
27 Leonavičiūtė I., Kariaunos vaidmuo kuriantis Lietuvos valstybei // Lietuvos valstybė XII-XVIII a., Vilnius, 1997, p. 475-485; Baranauskas T., Lietuvos valstybès ištakos, Vilnius, 2000, p. 172-178. Šioje polemikoje atsiskleidžia skirtingi požiūriai ị kariaunų vaidmeni XIII a. Lietuvoje, pakankamai dèmesio skiriama ir plèšiamiesiems žygiams.

28 Die Chronik Wigands von Marburg, hrsg. T. Hirsch // Scriptores rerum Prussicarum: Die Geschichtsquellen der preussischen, Bd. 2, Leipzig, 1863, s. 581.
}

29 Baronas D., Lietuvių karybos bruožai XIII a. pradžioje // Lietuvos valstybė XII-XVIII a., Vilnius, 1997, p. 494.

30 Petri de Dusburg, Chronicon terrae Prussiae, ed. M. Töppen // Scriptores rerum Prussicarum: Die Geschichtsquellen der preussischen, Bd. 1, Leipzig, 1861, s. 149-152. 
garbingiausias, jeigu toks smulkmeniškas autorius kaip Petras Dusburgietis jo neaprašo. Keršto siekis įžvelgiamas ir kituose šio laikotarpio karo veiksmuose. Matyt, neatsitiktinai Vytenis stengèsi sužinoti, kuris Vokiečių ordino riteris ji sužeide ${ }^{31}$. Akivaizdu, jog šiuo atveju buvo reikšmingi asmeniniai motyvai.

Didysis kunigaikštis jau XIII a. galëjo pavesti karines užduotis atlikti savo giminaičiams. Tai akivaizdžiai matyti iš gana intensyvios Vytenio veiklos dar jo tėvui valdant Lietuvos Didžiają Kunigaikštystę. Atrodo, tai ne tik leido ịgyvendinant valstybès politinius siekius išnaudoti dinastijos narius, bet ir buvo naudinga naujoms kartoms. Antroje valdymo puseje $(1310 \mathrm{~m}$.) ir didysis kunigaikštis Vytenis pasiuntè i Livoniją savo sūnų Žvelgaitį ${ }^{32}$. Ši žinia taip pat lakoniška, todèl Žvelgaičio žygio tikslai lieka neaiškūs. Žodžiai, jog kitais metais pats „karalius“ ‘̌ygiavo, neleidžia šio žygio ịsivaizduoti kaip plèšiamojo, nes sudaro kryptingos valstybinès politikos vaizdą.

Vytenis Lietuvos istoriografijoje pristatomas kaip geras ir aktyvus karo vadas. Jis dažnai renge žygius ị Prūsiją ${ }^{33}$, igijęs sajungininkų galèjo nuosekliau veikti Livonijoje ${ }^{34}$. Negalima pamiršti ir nuolatinio dèmesio Lenkijai ${ }^{35}$. Apie Vytenio žygius ị Rusios žemes šaltiniai tyli, tačiau tai nereiškia, jog jų nebuvo. Būtent Vytenio valdymo laikotarpiu susigrąžintas Polockas. Daugumai žygių Vytenis vadovavo pats, tačiau ne visiems. Kaip minèta, 1310 m. žygiui ị Livoniją vadovavo jo sūnus Žvelgaitis. Apie kitus giminaičius kalbèti sunku, nors organizuojant gynybą jie tikrai dalyvavo. Nuo 1305 m. minima Gedimino pilis Žemaitijoje ${ }^{36}$. Gedimino statusą dinastijoje iki Vytenio mirties analizavo Alvydas Nikžentaitis. Jo teigimu, 1305-1315 m. Gediminas buvo Vytenio submonarchas ir renge Žemaitijos gynybą: Gedimino pilis tuo laikotarpiu buvo ne tik pagrindinè didžiojo kunigaikščio atrama Vokiečių ordino nuolat puolamoje Žemaitijoje - joje dažniausiai buvo rengiami karo žygiai. Tačiau Gediminas pats nedalyvaudavo žygiuose, o šią pareigą atlikti pavesdavo didžiūnams, atvykusiems iš „tikrosios“ Lietuvos ${ }^{37}$. Ši hipotezė paremta diarchija, todèl ją reikètų iš naujo patikrinti.

31 Die Chronik Wigands von Marburg, hrsg. T. Hirsch // Scriptores rerum Prussicarum: Die Geschichtsquellen der preussischen, Bd. 2, Leipzig, 1863, s. 456.

32 Die Annalen und das Necrlologium von Ronnenburg, hrsg. E. Streblke // Scriptores rerum Prussicarum: Die Geschichtsquellen der preussischen, Bd. 2, Leipzig, 1863, s. 145.

33 Nikžentaitis A., Vytenis // Iš kur atèjome, Vilnius, 1988, p. 27.

34 Varakauskas R., Lietuvos ir Livonijos santykiai XIII-XVI a., Vilnius, 1982, p. 71.

35 Ivinskis Z., Lietuvos istorija iki Vytauto Didžiojo mirties, Vilnius, 1991, p. 217.

36 Petri de Dusburg, Chronicon terrae Prussiae, ed. M. Töppen // Scriptores rerum Prussicarum: Die Geschichtsquellen der preussischen, Bd. 1, Leipzig, 1861, s. 170.

37 Nikžentaitis A., Gediminas, Vilnius, 1989, p. 16-22. 
Kaip pabrěžia ir pats Alvydas Nikžentaitis, Gediminas iki Vytenio mirties jokiuose šaltiniuose nèra minimas, o jo veikla Žemaitijoje sietina su submonarcho statusu ir Gedimino pilimi. Tačiau jeigu Lietuvos Didžiojoje Kunigaikštysteje diarchija neegzistavo, ar galima teigti, kad taip anksti buvo paskirtas didžiojo kunigaikščio vietininkas Žemaitijoje, kuris turèjo atlikti bent jau karines funkcijas? Todèl reikètų grịžti prie šaltinių, remtis žiniomis, kurias mums paliko Petras Dusburgietis. Jis Gedimino pilį mini kelis kartus. Kaip išskirtinis gynybinis centras ji iškyla tik vieną kartą, būtent 1305 metais. Pasak kronikininko, vadovaujami Karaliaučiaus kontūro, 2000 raitelių ịsiveržè ị Pagraudès valsčių ir jị nusiaubè, o paskui nuo ryto iki pietų stovejjo prie Gedimino pilies. Apie jos puolimą nėra žinių, tik grịžtanti kariuomenè sunaikino paskui sekusi 20 lietuvių būrị ${ }^{38}$. Reikia sutikti, jog pilis turẻjo būti gerai ịtvirtinta, o jos ịgula pakankamai stipri, jei tokios pajègos nesiryžo jos pulti. Tačiau vèlesni kronikos aprašymai liudija, kad Gedimino pilis Žemaitijoje tapo gerokai mažesnių karinių jègų puolimo objektu ir patyre gana žymių nuostolių ${ }^{39}$. Tai galima aiškinti prielaida, jog pilis buvo pastatyta maždaug $1305 \mathrm{~m} .{ }^{40}$, o Vokiečių ordinas ją puolè, kai ten buvo sutrauktos didelès pajègos. Veikiausiai joje galèjo būti ir pats Gediminas. Tačiau vèliau jis Žemaitijos ivvykiuose neminimas. Tai stebina, kadangi Gediminas apibūdinamas kaip geras karvedys, nors šioje srityje ir nebuvęs veiklus ${ }^{41}$. Susidaro įspūdis, jog Gediminas Žemaitijoje veikè epizodiškai, nes kitaip sunku paaiškinti, kaip toks karo vadas galejjo visą iniciatyvą karo metu perleisti didžiūnams, pasilikdamas sau tik administravimo funkcijas. Gal tik žemaičių nuraminimo akcijai įvykdyti ir centrui sukurti Gediminas retkarčiais buvo siunčiamas į Žemaitiją? Kad taip ir buvo, galima spręsti ir iš kitų žinių. Atrodo, jog 1306 m., Sembos vaitui surengus žygị i Lietuvą, buvo puolama Žemaitija. Pats karalius èmè juos persekiotiti ${ }^{42}$. Matyt, Vytenis, kiek buvo įmanoma, asmeniškai stengèsi rūpintis Žemaitijos gynyba.

Vytenio, kaip karo vado, aktyvumas, nepaisant nesėkmių žygiuose, akivaizdus. Jis į karo veiksmų rengimo procesą visiškai neįtraukè savo giminaičių. Šaltiniai, be Vytenio, nemini jokių kitų asmenų, tik kariuomenę. Sunku patikèti, jog Vytenis nè viename iš savo žygių giminaičiais nesirèmè. Tačiau tai, kad šaltiniai

38 Petri de Dusburg, Chronicon terrae Prussiae, ed. M. Töppen // Scriptores rerum Prussicarum: Die Geschichtsquellen der preussischen, Bd. 1, Leipzig, 1861, s. 170.

39 Ten pat, p. 183; 189; 190; 193; 217.

40 Nikžentaitis A., Nuo Daumanto iki Gedimino. Ikikrikščioniškos Lietuvos visuomenès bruožai // Acta historica Universitatis Klaipedensis, T. 5, Klaipėda, 1996, p. 63.

41 Nikžentaitis A., Gediminas, Vilnius, 1989, p. 92-94.

42 Petri de Dusburg, Chronicon terrae Prussiae, ed. M. Töppen // Scriptores rerum Prussicarum: Die Geschichtsquellen der preussischen, Bd. 1, Leipzig, 1861, s. 171-172. 
apie juos tyli, rodo, jog jie nebuvo itin svarbūs. Kartu reikia pridurti - kartais vieniems ar kitiems karo veiksmams vadovauti buvo patikima artimiausiems giminaičiams, ką liudija Žvelgaičio žygis į Livoniją ar Gedimino epizodas Žemaitijoje, nors procesai ir buvo skirtingi. Vytenio valdymo laikotarpiu didžiajam kunigaikščiui buvo svarbu karo žygiuose pačiam dalyvauti, o neišplètotos valstybės komunikacijos leido tai daryti. Periferija buvo pavaldinių, bet ne dinastijos narių rankose. Kaip ir visas karybos procesas. Vytenio valdymo laikotarpio šaltiniuose nèra né vienos žinutès apie tai, kad karalius žygiavo su savo broliais. Ir tai, atrodo, mažiausiai keista. Jau Vytenio ịpédiniui Gediminui, siekiant kuo geriau pasirengti karo veiksmams, reikèjo ieškoti kitokių sprendimų.

\section{POKYČIAI GEDIMINO VALDYMO LAIKOTARPIU}

Gedimino apibūdinimas istoriografijoje jau nusistovèjęs. Visų pirma pabrèžiama, jog jis buvęs geras diplomatas, gebejjęs įvertinti riziką, pasinaudoti priešo silpnumu ir dinastinès diplomatijos teikiamomis galimybèmis, kas leido plèsti valstybę, sudaryti patikimas sajungas su artimiausiais kaimynais ${ }^{43}$. Nors Gediminas pirmiausia ịvertinamas kaip diplomatas, nepamiršti ir jo karybos gebėjimai. Tačiau apibūdinant Gediminą kaip karo vadą pabréžiama, kad šis valdovas neišnaudojo savo potencialo, o karo žygiai jam buvo tam tikra diplomatine priemonè. Gediminas juose dalyvaudavo tada, kai reikejo pademonstruoti savo galimybes - suteikti pagalbą sajungininkams ${ }^{44}$.

Gedimino laikais pradejo itin aiškiai išsiskirti Lietuvos Didžiosios Kunigaikštystès valdovo ir karo vado funkcijos. Nors šis procesas nebuvo naujas, jo ištakų galima ieškoti dar XIII a. Lietuvos visuomenèje ${ }^{45}$. Tačiau Gedimino kaip karo vado pasyvi laikysena, palyginti su Vytenio kariniu aktyvumu, itin skiriasi. Reikia pripažinti istoriografinę tiesą, kad Gediminas visų pirma buvo diplomatas. Jo veiklos rezultatas - nuosekli valstybės plètra ị Rusią, dėl ko Lietuvos Didžiosios Kunigaikštystės struktūra darèsi vis sudètingesnè. Buvo siekiama ne tik suvienyti aplinkines žemes, bet ir patenkinti dinastijos interesus ${ }^{46}$. Dèl to neišvengiamai keitèsi karinė organizacija, pirmiausiai siekiant kiek įmanoma panaudoti didžiulius dinastijos išteklius.

43 Rowell S. C., Iš viduramžiu ūku kylanti Lietuva: Pagonių imperija Rytų ir Vidurio Europoje, 1295-1345, Vilnius, 2001, p. 93-101.

44 Nikžentaitis A., Gediminas, Vilnius, 1989, p. 94.

45 Nikžentaitis A., XIII-XV a. lietuvių kariuomenès bruožai (organizacija, taktika, papročiai) // Karo archyvas, T. 13, 1992, p. 21-22.

46 Norkus Z., Nepasiskelbusioji imperija: Lietuvos Didžioji Kunigaikštija lyginamosios istorinès imperijų sociologijos požiūriu, Vilnius, 2009, p. 243. 
Žinių apie Gedimino karinių veiksmų organizavimo ypatumus, palyginti su Vytenio laikų kariniais veiksmais, išliko pakankamai. Kaip minėta, karo veiksmų metu pradejjo kisti valdovo vaidmuo. Didysis kunigaikštis nebeprivalejjo nuolat dalyvauti karo žygiuose, dažniausiai jis pasilikdavo organizatoriaus vaidmeni, sprendžiant iš to, kaip nuosekliai buvo planuojami žygiai, kurie tenkino nebe kariaunų plèšikiškus užmojus, bet buvo valstybès konkrečios užsienio ir santykių su kaimynais politikos ir siekių išraiška ${ }^{47}$.

Gediminas pradejo nuosekliai remtis savo artimiausiais giminaičiais. Tai matoma jau pirmaisiais jo valdymo dešimtmečiais, nors procesas tęsèsi ir keičiantis kartoms. Ypač tai aktualu buvo didelio masto operacijose. Tokia operacija laikytinas ir jo žygis į Pietvakarių Rusią, kuris pakeitė regiono geopolitinę situaciją, žinomas iš Lietuvos metraštinès tradicijos. Nors turime ,istorinès tradicijos“ apnašomis padengtą pasakojimą ${ }^{48}$, kiti šaltiniai taip pat suteikia papildomų duomenų. Istoriografijoje sutariama, kad Gediminas tokio masto kampaniją galëjo surengti tik užtikrinęs savo valstybès saugumą. Jis sutelkè dideles pajègas ir ịsiveržè pirmiausia ị Voluinès žemę, vẻliau - į Kijevą. Realių dinastinių ir valstybinių laimėjimų Voluinèje Gediminas nepasiekè, tam prielaidos atsirado vèliau ${ }^{49}$, tačiau žygio ị Kijevą rezultatai buvo svaresni - Gediminas šioje kunigaikštystëje paliko savo vietininką. Sprendžiant iš to, jog Kijevo kunigaikštis buvo Gedimino brolis Teodoras $^{50}$ (Algimantas Mindaugaitis geriausiu atveju galejo būti jo aplinkos asmuo, nors tikimybè didesnè, kad jis dalyvavo žygyje jau valdant Algirdui, kai šioje žemèje „pasodino“ savo sūnų Vladimirą). Gediminas ị karo žygius pradeda įtraukti savo brolius. Ši prielaida tampa dar realesnè išanalizavus Hermano Vartbergès pasakojimą apie Gedimino ịsiveržimą į Livoniją 1329 m., kuriame aiškiai pasakoma, jog karo žygyje dalyvavo lietuvių „karalius“ ir du jo broliai ${ }^{51}$. Čia jau nedviprasmiškai kalbama apie tai, kad Gediminas stengiasi ị karo žygius ittraukti dinastiją, nes teritorijos plètra pirmiausia buvo naudinga jos nariams.

Gediminas pradejo nuosekliai tvarkyti valstybès periferijos klausimus. Jos valdymą, taip pat ir gynybą, buvo siekiama padaryti efektyvesni. Vienas ryškiausių tokių pastangų pavyzdžių - Polocko kunigaikštystès valdymas ir

47 Rowell S. C., Iš viduramžiu ūku kylanti Lietuva: Pagonių imperija Rytų ir Vidurio Europoje, 1295-1345, Vilnius, 2001, p. 88-93.

48 Jasas R., Bychovco kronika ir jos kilme // Lietuvos metraštis: Bychovco kronika, Vilnius, 1971, p. 8-10.

49 Plg.: Tęgowski J., Pierwsze pokolenia Giedyminowiczów, Poznań-Wrocław, 1999, s. 335-336.

50 Batūra R., Lietuva tautu kovoje prieš Aukso Ordą: Nuo Batu antplūdžio iki mūšsio prie Mèlynųju Vandenu, Vilnius, 1975, p. 186-200.

${ }_{51}$ Hermani de Wartberge, Chronicon Livoniae, hrsg. E. Streblke // Scriptores rerum Prussicarum: Die Geschichtsquellen der preussischen, Bd. 2, Leipzig, 1863, s. 63-65. 
gynybos organizavimas. Nors Polockas tapo Vyteniui pavaldus gana anksti ${ }^{52}$, nepanašu, kad ị šios kunigaikštystès reikalus jis būtų labai kišęsis. Atrodo, kunigaikštystė tvarkèsi gana savarankiškai. Tai galima suprasti iš Polocko vyskupo Jakovo laiško Rygos arkivyskupui ${ }^{53}$. Gedimino valdymo laikotarpiu Polocko kunigaikštis buvo jo brolis Vainius ${ }^{54}$. Tuo pat metu iškyla dar viena ryški figūra - Žemaitijoje veikęs „karalius“ Margiris. Manoma, jog tai galèjo būti Gedimino brolis ${ }^{55}$, tačiau yra teigiančių, jog Margiris nebuvo toks artimas valdovo giminaitis ${ }^{56}$. Hermano Vartbergès kronikos žinios ir išskirtinis jo statusas, priešingai negu Vytenio laikais veikusių kelių didžiūnų, leidžia pirmają nuomonę laikyti artesne tiesai, o tai tik dar kartą patvirtina, jog valstybès periferija Gedimino laikais tapo itin svarbi, nes valdžia ten buvo perleista artimiausiems valdovo giminaičiams. Jis stengèsi ị karybos ir administracijos reikalus ịtraukti ne tik savo brolius, bet ir sūnus. Tiesa, šis procesas tapo matomas tik paskutiniame Gedimino valdymo dešimtmetyje. Pirmiausiai minimas Narimantas, kuri tėvas 1333 m. išsiunte i Didiji Naugardą ${ }^{57}$. Kokiu tikslu ị Naugardą ir Pskovą vykdavo lietuviai kunigaikščiai, išsamiai yra aprašęs S. C. Rowellas. Pirmiausia jie turejjo rūpintis karybos reikalais, gynyba. Lietuvių kunigaikščių, kurie netenkindavo šių poreikių, paslaugų buvo atsisakoma ${ }^{58}$. Išvykdamas iš Naugardo Narimantas vietoj savęs paliko sūnų Aleksandrą ${ }^{59}$. Gali būti, jog tai sietina su tuo, jog Narimantas gavo Polocko kunigaikštystę: 1338 m. jis Polocko vardu sudarė sutartị su Livonija ${ }^{60}$. Sunku ịsivaizduoti, kad Narimantas gana jauną sūnų būtų palikęs be didžiojo kunigaikščio žinios. Atrodo, Gediminas i karo veiksmus ịtraukè ne tik savo sūnus, bet ir anūkus. $1337 \mathrm{~m}$. epizodas prie Bajerburgo, kur žuvo „Trakų karalius“, taip pat daug ką pasako apie Gedimino santykius su giminaičiais, veikiausiai sūnumi. Vygandas Marburgietis, pasakodamas apie žygi, mini ir patị Gediminą, tačiau ji aiškiai skiria nuo „Traku

52 Pašuta V., Lietuvos valstybès susidarymas, Vilnius, 1971, p. 295.

53 Полоцкие грамоты ХIII - начала XVI вв., состав. А. Л. Хорошкевич, Т. 1, М., 1978, c. $37-38$.

54 Новгородская первая летопись старшего и младшего извода, М.-Л., 1950, с. 98.

55 Nikžentaitis A., Gediminas, Vilnius, 1989, p. 9-11.

56 Rowell S. C., Iš viduramžiu ūkų kylanti Lietuva: Pagonių imperija Rytų ir Vidurio Europoje, 1295-1345, Vilnius, 2001, p. 256.

57 Новгородская первая летопись старшего и младшего извода, М.-Л., 1950, с. 345-346.

58 Rowell S. C., Iš viduramžiu ūku kylanti Lietuva: Pagonių imperija Rytų ir Vidurio Europoje, 1295-1345, Vilnius, 2001, p. 253-254.

59 Tęgowski J., Pierwsze pokolenia Giedyminowiczów, Poznań-Wrocław, 1999, s. 28.

60 Полоцкие грамоты ХІІІ - начала ХVI вв., состав. А. Л. Хорошкевич, Т. 1, М., 1978, c. $39-41$. 
karaliaus“, kuriuo laikytas aštuntasis didžiojo kunigaikščio sūnus Vytautas ${ }^{61}$. Kiek šis spejjimas teisingas, kitas klausimas, tačiau tai, kad „Traku karalius“ buvo artimas Gedimino giminaitis, o gal ir sūnus, neabejotina.

Šaltiniuose gana daug žinių ir apie Lietuvos Didžiojoje Kunigaikštystėje buvusias Gedimino sūnu valdas: 1338 m. Narimantas valde Polocka, Algirdas - Vitebską ${ }^{62}$, po 1337 m. ìvykių prie Bajerburgo Kęstutis gavo Trakus ${ }^{63}$. Dèl Manvydo valdų Kernaveje ir Slonime ir Karijoto žemių Naugarduke neaišku ${ }^{64}$, tačiau galima daryti prielaidą, kad jos galèjo būti perduotos valdyti Gedimino valdymo pabaigoje. Jaunučio padètis tuo metu taip pat neaiški. Veikiausiai kažkokią nedidelę valdą jis turèjo etninèje Lietuvoje, o gal gyveno tèvo dvare. Šis klausimas lieka atviras. Akivaizdu, jog šie žingsniai žengti ne tik ịpédinių interesams patenkinti ${ }^{65}$, bet ir siekiant tobulinti valstybės administravimą, taip pat geriau organizuoti jos gynybą. Toliausiai nuo valstybès centro buvęs sūnus Liubartas po Boleslovo - Jurgio II - mirties aktyviai veikè Voluinejje, neilgai buvo ịsitvirtinęs jo valdytoje teritorijoje ${ }^{66}$. Atrodo, kad nei tèvui, nei broliams šioje situacijoje įsikišti nereikejo, ir Liubartas susitvarkè su savo pajègomis.

Gedimino sukurta sistema, turëjusi patenkinti ịpėdinių ambicijas, funkcionavo neilgai ${ }^{67}$. Net po jo mirties ji nesugriuvo, tiesiog buvo pertvarkyta, nes netenkino ịpėdinių interesų, neužtikrino stabilių hierarchinių santykių. Tai akivaizdžiai atsiskleidžia analizuojant 1342 m. ivykius.

Livonijos ordinas puolè Pskovo žemę. Pskoviečiai, nesulaukę pagalbos Naugarde, kreipèsi ị tradicinius savo sajungininkus lietuvius, konkrečiai i Vitebsko kunigaikštị Algirdą. Šis neatsisakė padèti. Iš aprašymo galima spręsti, kad paramos kampanija buvo organizuota itin plačiai - be Algirdo,

61 Nikžentaitis A., Gediminas, Vilnius, 1989, p. 13-15.

62 Napiersky K. E., Russisch-livländische Urkunden, St. Petersburg, 1868, p. 69; Liv.-Esth.- und Curländisches Urkundenbuch nebst Regesten, Hrsg. von F. G. Bunge, Bd. 2, Reval, 1855, sp. 333.

63 Gudavičius E., Lietuvos valstybès struktūra Gedimino laikais // Metai, Nr. 1, Vilnius, 1992, p. 125.

64 Полное собрание русских летописей, Т. 35: Летописи белорусско-литовские, М., 1980, c. 61.

65 Norkus Z., Nepasiskelbusioji imperija: Lietuvos Didžioji Kunigaikštija lyginamosios istorinès imperiju sociologijos požiūriu, Vilnius, 2009, p. 243.

66 Шабульдо Ф. М., Земли Юго-Западной Руси в составе Великого княжества Литовского, Киев, 1987, с. 37-40.

67 Rowell S. C., Iš viduramžių ūkų kylanti Lietuva: Pagonių imperija Rytų ir Vidurio Europoje, 1295-1345, Vilnius, 2001, p. 298-306. 
žygyje dalyvavo Trakų kunigaikštis Kęstutis ir dar keli dinastijos nariai ${ }^{68}$. Istoriografijoje atmetama didžiojo kunigaikščio Jaunučio vadovavimo galimybe ir abejojama, jog jis apskritai sankcionavo šį žygi ${ }^{69}$. Iš aprašymo aiškejja, kad vadovavo Algirdas. Pirmiausia jis išsiunte kunigaikšti Jurgi Vytautaitį, kuris apibūdinamas kaip Algirdo karvedys ${ }^{70}$. Neaišku, ar jis priklausė dinastijai, tačiau tokių prielaidų esama ${ }^{71}$. Žinoma, kad su Algirdu ir Kęstučiu žygyje dalyvavo ir Liubka, Gedimino brolio Vainiaus, Polocko kunigaikščio, sūnus (šiose kovose jis ir žuvo). Metraštininkas nurodo, kad Liubkos žūtis daug skausmo sukèlè Algirdui ir Kęstučiui, taip pat kitiems kunigaikščiams ${ }^{72}$. Iš to galima spręsti, jog šiame žygyje dalyvavo didesnès pajègos, nors smulkiau jos ir neskirstomos. Iš „kitų kunigaikščių“ pirmiausiai galime išskirti Andrių Algirdaiti, kuris minimas aprašyme, nes vèliau buvo paliktas Pskove vietininku $^{73}$. Tačiau tikètina, kad čia galëjo būti ir daugiau Algirdo ir Kęstučio palikuonių, galbūt net kuris nors brolis (nors abejotina, veikiausiai metraštininkas būtų tokias detales paminėjęs). Vis dèlto akivaizdu viena - Pskovo žemejje esanti lietuvių kariuomenè buvo gana didelè, todèl Algirdui nebuvo sunku ją išskaidyti dalimis: Jurgis Vytautaitis su nedidele kariauna buvo pasiųstas ị Naugardą (tačiau jis, susidūręs su vokiečiais, užsidarè Izborske), Liubka Vainaitis, atsitraukęs nuo Algirdo, kovoje su sargybiniu vokiečių pulku žuvo. Tačiau nepaisant to, jog dinastijos nariai galejo gana laisvai disponuoti nedideliais būriais, pagrindinès pajègos vis dèlto buvo sutelktos ${ }^{74}$.

Tai, kad buvo apeitas didysis kunigaikštis Jaunutis, ir žygio mastas rodo, jog dinastinè struktūra rengiant karo žygius tinkamai neveikè. Kęstučio parama Algirdui liudija, jog didysis kunigaikštis šioje srityje buvo praradęs iniciatyvą, o pats žygis atskleidžia Algirdo padètị valstybeje. Dar Gedimi-

68 Полное собрание русских летописей, Т .4: Новгородская 4-я и Псковская 1-я летописи, СПб, 1848, с. 56.

69 Rowell S. C., Iš viduramžiu ùku kylanti Lietuva: Pagonių imperija Rytų ir Vidurio Europoje, 1295-1345, Vilnius, 2001, p. 302-303.

70 Полное собрание русских летописей, Т. 4: Новгородская 4-я и Псковская 1-я летописи, СПб, 1848, с. 56.

71 Tęgowski J., Pierwsze pokolenia Giedyminowiczów, Poznań-Wrocław, 1999, s. 45-46. Šiai nuomonei oponuoja Rowell S. C., Iš viduramžiu ūkų kylanti Lietuva: Pagoniu imperija Rytų ir Vidurio Europoje, 1295-1345, Vilnius, 2001, p. 299.

72 Полное собрание русских летописей, Т. 4: Новгородская 4-я и Псковская 1-я летописи, СПб, 1848, с. 56.

73 Полное собрание русских летописей, Т. 5: Псковская 2-я и Софийская 1-я летописи, СПб, 1851, с. 224.

74 Полное собрание русских летописей, Т. 4: Новгородская 4-я и Псковская 1-я летописи. СПб, 1848, с. 55-57. 
no „testamente“ nurodoma, kad Polocko kunigaikščiu 1338 m. buvęs Narimantas gavo Pinską, nors „testamente“ Polockas nefigūruoja ir kunigaikščio klausimas iki Andriaus Algirdaičio paskyrimo ten yra atviras ${ }^{75}$. Tačiau Algirdo ịtaka šioje žemejje abejonių nekelia. Tai rodo Liubkos Vainaičio dalyvavimas karo kampanijoje. Metraštininkas neatsitiktinai Algirda sieja su Polocku. Jis ten galejjo turèti kažkokių valdų, paveldètų iš tèvo, panašiai kaip Karijotaičiai, kurie vėliau disponavo valdomis Naugarduko kunigaikštystejje, nors žinomi ir kiti Naugarduko kunigaikščiai ${ }^{76}$. Galbūt Jurgị Vytautaitị taip pat reikètu sieti su Polocku? Akivaizdu tik tai, jog šis kunigaikštis turejjo veikti Rusios žemėse, ką rodo jo krikšto vardas. Žygio užmojai ir rezultatai buvo naudingiausi Algirdui, kuris sutvirtino autoritetą Pskove ir, siekdamas užtikrinti dinastijos interesus, paliko ten savo sūnu . Kartu reikètu pabrèžti, kad Algirdo prerogatyvos LDK buvo platesnès, negu atskleidžia Gedimino „testamentas“: jis disponavo ne tik palikimu - Krèvos ir Vitebsko kunigaikštystėmis, bet ir dare ịtaką rytinėms LDK pasienio žemėms, tokioms kaip Polockas. Būtent ši įtaka po Gedimino mirties pažeidė dinastijos pusiausvyrą ir išryškino Algirdo interesus LDK rytuose. Jaunutis, kaip LDK valdovas, taip ir nebesièmé organizuoti karo veiksmų ${ }^{77}$, o tai rodo, kad jo valdžia silpo. To padariniu laikytinas ir $1345 \mathrm{~m}$. perversmas. Nors grindžiant ši pastebejjimą taip pat reikètų padaryti išlygų. $1343 \mathrm{~m}$. Livonijos ir Pskovo konfliktas toliau tęsèsi. I Pskovo žemę ịsibrovė Livonijos ordino kariuomenè, kuriai vadovavo krašto magistras Burhardas. Tuo puikiai pasinaudojo Algirdas ir Kęstutis, kurie tuo metu ịsiverže i Livoniją ir trimis kryptimis nužygiavo plěšdami apylinkes ${ }^{78}$. Jeigu du vadai aiškūs, kyla klausimas, kas buvo trečiasis. Ar tai galejo būti Jaunutis? Šis klausimas akivaizdžiai liudija šaltiniotyros problemas ir neleidžia daryti griežtų išvadų.

Vis dėlto 1345 m. perversmo, sąmokslo prieš Jaunutị, padariniai akivaizdūs: Gedimino sukurta teritorine ir hierarchine dinastijos sistema buvo pertvarkyta, dèl to pasikeitè ir jos pobūdis. Priešingai negu buvo numatyta Gedimino, didysis kunigaikštis pirmiausia turejo remtis ne dinastijos nariais (kaip buvo Jaunučio atveju, tiesa, nesèkmingai), o karine galia. Algirdui užvaldžius Vilnių, didžiajam kunigaikščiui karine galia ir įtaka dinastijoje niekas nebegalejo prilygti.

75 Полное собрание русских летописей, Т. 35: Летописи белорусско-литовские, М., 1980 , c. 61.

76 Plg.: Tęgowski J., Pierwsze pokolenia Giedyminowiczów, Poznań-Wrocław, 1999, s. 201.

77 Rowell S. C., Iš viduramžiu ūku kylanti Lietuva: Pagoniu imperija Rytu ir Vidurio Europoje, 1295-1345, Vilnius, 2001, p. 302.

78 Die Chronik Wigands von Marburg, hrsg. T. Hirsch // Scriptores rerum Prussicarum: Die Geschichtsquellen der preussischen, Bd. 2, Leipzig, 1863, s. 501-502. 


\section{DINASTIJOS PLÉTROS LAIKOTARPIS IR GEDIMINO SISTEMOS ŽLUGIMAS (1345-1383 M.)}

İsitvirtinant valdžioje Algirdui pirmiausia reikèjo nustatyti santykius su kitais dinastijos nariais. Išskirtinēje pozicijoje šiuo atveju atsidūre Kęstutis, sąmokslo prieš Jaunuti vykdytojas. Su tuo Algirdui teko susitaikyti. O kiti broliai buvo priversti Algirdui paklusti. Nesusitaikę su pasikeitusia padėtimi Jaunutis ir Narimantas pabėgo ieškoti paramos: pirmasis - i Maskvą, antrasis - pas totorius ${ }^{79}$. Tačiau apčiuopiamų rezultatų nepasiekę buvo priversti grižti ị Lietuvos Didžiają Kunigaikštystę ir paklusti Algirdui.

Algirdas taip pat turejjo atkreipti dèmesị i ryšius su periferija, nes valstybè, kartu ir jos įtaka, labai išsiplètė: Kijevo santykiai su Lietuvos didžiuoju kunigaikščiu tuo metu buvo neaiškūs, nors ten ir valdè Algirdo dėdė Teodoras ${ }^{80}$, Pskove taip pat „sėdëjo“ Lietuvos kunigaikščiai ${ }^{81}$. Jau artèjo Vokiečių ordino krizės pabaiga, tačiau santykiai su Lenkija dèl Pietvakarių Rusios žemių buvo neapibrěžti, o su Maskva ir totoriais - nepastovūs. Šiame kontekste ir reikètų analizuoti didžiojo kunigaikščio veiksmus telkiant dinastijos narius kariniams reikalams spręsti.

Algirdas, organizuodamas krašto gynybą, veikė aktyviai. Vakarų kryptimi 1345-1348 m. kartu su Kęstučiu buvo rengiami žygiai tiek ị Prūsiją ${ }^{82}$, tiek ị Livoniją $^{83}$, nuo 1347 m. juose dalyvavo ir Narimantas ${ }^{84}$. Ne mažiau Algirdui buvo svarbi ir Rytų kryptis. 1346 m. jis su savo broliais ir visomis Lietuvos pajègomis įsiveržè į Naugardo žemę ${ }^{85}$. Neaišku, kas buvo tie broliai, pirmiausia turbūt Kęstutis, galbūt dar Manvydas ir Karijotas. Vis dèlto toliau dinastiją telkti sutrukdè $1348 \mathrm{~m}$. prie Strèvos patirtas pralaiméjimas.

Sprendžiant iš Vygando Marburgiečio aprašymo, Algirdas gana greitai galëjo surinkti didelę LDK kariuomenę ne tik iš lietuvių, bet ir iš Rusios

79 Полное собрание русских летописей, Т. 4: Новгородская 4-я и Псковская 1-я летописи. СПб, 1848, с. 57.

80 Jankauskas V., Kijevo žemès statusas Lietuvos Didžiojoje Kunigaikštystëje (XIV-XV amžiai) // Darbai ir dienos, T. 44, Kaunas, 2005, p. 85.

81 Новгородская первая летопись старшего и младшего извода, М.-Л., 1950, с. 354.

82 Die Chronik Wigands von Marburg, hrsg. T. Hirsch // Scriptores rerum Prussicarum: Die Geschichtsquellen der preussischen, Bd. 2, Leipzig, 1863, s. 508-514.

83 Hermani de Wartberge, Chronicon Livoniae, hrsg. E. Streblke // Scriptores rerum Prussicarum: Die Geschichtsquellen der preussischen, Bd. 2, Leipzig, 1863, s. 72-75.

84 Die Chronik Wigands von Marburg, hrsg. T. Hirsch // Scriptores rerum Prussicarum: Die Geschichtsquellen der preussischen, Bd. 2, Leipzig, 1863, s. 508. (Kad Narimantas dalyvavo, žinoma iš Kasparo Šiuco darbo.)

85 Новгородская первая летопись старшего и младшего извода, М.-Л., 1950, с. 358-359. 
žemių. Tiesa, nurodomos ir tos žemès, kurios tuo metu LDK nepriklausė (Smolenskas) ir dèl kurių dalyvavimo galima būtų abejoti (Vladimiras), tačiau tai tik dar kartą rodo, kaip veiksmingai Algirdas galëjo disponuoti Rusios pajëgomis ${ }^{86}$. Jis šiame žygyje sutelkẻ didžiają dalį dinastijos pajëgų, ir tai užfiksuota šaltiniuose. Hermanas Vartberge nurodo, kad Strèvos mūšyje žuvo Algirdo brolis Narimantas ${ }^{87}$, o Motiejaus Nojenburgiečio kronikoje rašoma, jog ten galvas padejo du Algirdo broliai ${ }^{88}$. Spejjama, kad antrasis galëjo būti Manvydas ${ }^{89}$. Tai, atrodo, logiška dèl kelių priežasčių. Pirma, Manvydas daugiau niekur neminimas, išskyrus Gedimino „testamentą“ - veikiausiai jis netrukus mirè. Kita priežastis yra tai, jog Algirdui renkant pajègas iš Rusios vargu ar brolis, valdęs dalị etninių lietuvių žemių (Kernavės kunigaikštystę), galèjo likti nuošalyje rengiant tokio masto žygị. Beje, kiti Gedimino sūnūs veikè ir vėlesniais laikais, todèl toks paaiškinimas visiškai argumentuotas.

Strèvos mūšio padariniai vertinami ịvairiai pirmiausia dèl pakitusio karinio LDK potencialo. Abejojama, ar ten patirtas pralaimejjimas buvo toks skaudus, kaip rašoma šaltiniuose. Akivaizdu viena - kurị laiką Algirdas nedalyvavo žygiuose ị Vokiečių ordino teritoriją (iki didelio žygio, surengto $1352 \mathrm{~m}$. ) $^{90}$ galbūt dèl to, jog buvo užimtas - reikèjo pasirūpinti santykiais su totoriais ir Maskva ${ }^{91}$. Algirdas nesikišo ir i Liubarto konfliktą su Lenkijos karaliumi Kazimieru III, kurio metu pagalbą broliui suteikè Kęstutis. Jis iki 1351 m. šiame fronte buvo aktyvesnis negu reguliuojant santykius su Vokiečių ordinu ${ }^{92}$. Konfliktas su Lenkija Pietvakarių Rusioje atskleidè, jog didysis kunigaikštis kai kuriuose karo veiksmuose nedalyvavo. Tam ịtakos galëjo turèti ịtampa rytinèje valstybės dalyje. Dèl šios priežasties Algirdui teko pasitelkti i pagalbą brolius ir kitus dinastijos narius. Tuo metu aiškiai formavosi kelios kovos dèl įtakos sritys: Algirdas rūpinosi santykiais su Rytais, Kęstutis - su Ordinu, Liubartas - su Lenkija. Tačiau veikta ne atskirai - tarp jų matyti labai aiškūs saitai. Ko gero, geriausiai tai iliustruoja 1349-1352 m. karo su Lenkija eiga.

Algirdas, telkdamas karinį valstybès potencialą, daugiausia dėmesio sky-

86 Die Chronik Wigands von Marburg, hrsg. T. Hirsch // Scriptores rerum Prussicarum: Die Geschichtsquellen der preussischen, Bd. 2, Leipzig, 1863, s. 510-514.

87 Hermani de Wartberge, Chronicon Livoniae, hrsg. E. Streblke // Scriptores rerum Prussicarum: Die Geschichtsquellen der preussischen, Bd. 2, Leipzig, 1863, s. 76.

88 Die chronik des Mathias von Neuenburg, hrsg. G. Grandaur, Leipzig, 1899, s. 165.

89 Nikžentaitis A., Ivadas // Kučinskas A., Kęstutis, Vilnius, 1988, p. VII.

90 Die Chronik Wigands von Marburg, hrsg. T. Hirsch // Scriptores rerum Prussicarum: Die Geschichtsquellen der preussischen, Bd. 2, Leipzig, 1863, s. 516-519.

91 Puzyna J., Koriat i Koriatowicze // Ateneum Wilenskie, T. 7, Z. 3-4, Wilno, 1930, s. 427.

92 Kučinskas A., Kęstutis, Vilnius, 1988, p. 100-105. 
rẻ Rytų krypčiai. Tai laikytina natūraliu procesu, kadangi valstybės rytiniame pasienyje plytėjo jam tiesiogiai pavaldžios žemès. Ši Algirdo interesų kryptis išryškejjo dar Gedimino ir Jaunučio valdymo metais. Tačiau Algirdas nenusišalino nuo valstybės interesų, kuriuos gynè ir Vakaruose: aktyviai buvo bendradarbiaujama su broliais Kęstučiu ir Liubartu, abu buvo ịtraukti ị Rytų kampanijas. Tokiu būdu dinastija galejo veikti kaip suderintas mechanizmas ir užtikrinti, kad valdžia ir karinès pajègos tinkamai funkcionuotų.

Nuo pat pradžios Algirdo gebėjimas telkti dinastijos narius buvo akivaizdus, ką iliustruoja ir XIV a. penktojo dešimtmečio žygiai į Naugardą. Šia kryptimi Algirdas veikè aktyviai. Metraštininkai atskirai net nenurodo Algirdo žygių motyvų, kas liudija šių veiksmų intensyvumą. 1346 m. žygio priežastimi laikomas Algirdo ịžeidimas, ị kurị buvo atsakyta Naugardo valsčių apiplěšimu. Algirdo surinktoje didelejje kariuomenejje buvo jo „broliai ir kunigaikščiai“"93. Tarp jų išskirtinai atrodo Kęstutis (minimas tik Nikono metraštyje $)^{94}$. Šia kryptimi Algirdas aktyviausiai veike pirmaisiais savo valdymo metais. Iki 1348 m. Pskove ir toliau vadovavo jo sūnus Andrius ir Jurgis Vytautaitis (pastarasis per susidūrimą su vokiečiais žuvo prie Izborsko). Po to pskoviečiai atsisakẻ Andriaus, ir tai sukèle konfliktą. Iš aprašymo metraštyje aiškejja, jog Algirdas tuo metu buvo žygyje, Naugarde, o grịždamas užpuolė Pskovą. Kitais metais į Pskovo žemes įsiveržè Polocko kunigaikštis Andrius Algirdaitis ${ }^{95}$. Akivaizdu, kad Algirdas nuo pat valdymo pradžios rèmėsi artimiausiais giminaičiais, pirmiausia broliais ir sūnumis. Tačiau Algirdo aktyvumas Rusioje jau XIV a. šeštojo dešimtmečio pradžioje gerokai sumenko po 1352 m. susidūrimų su Maskvos pajègomis prie Smolensko, nors šiuo atveju negalima pamiršti ir pralaimėjimo Strèvos mūšyje, besimezgančių dinastijos saitų su Rusios kunigaikščiais ir nesėkmingos Karijoto pasiuntinystès pas totorius ${ }^{96}$. Rytuose Algirdas buvo pasyvus iki dešimtmečio vidurio.

$1356 \mathrm{~m}$. vèl prasidejo kampanijos ị Rusią. Be pastangų ịsitvirtinti Šiaurès Rusioje, pirmiausia Smolenske, pradejjo ryškèti Algirdo siekis plèsti ịtaką ir pietų kryptimi. Nikono metraštyje rašoma, kad Algirdas kariavo Smolenske ir Brianske, tačiau smulkiai nerašoma, kaip vyko šie karo žygiai. Galima tik numanyti, jog Algirdui pavyko ịsitvirtinti Brianske, nes šioje kunigaikštysteje iš Aukso ordos atvykusiam kunigaikščiui Vasilijui nepavyko sustiprinti savo pozicijų ir prieš

93 Новгородская первая летопись старшего и младшего извода, М.-Л., 1950, с. 358-359.

94 Полное собрание русских летописей, Т. 10: Летописный сборник, именуемый Патриаршею или Никоновскою летописью. СПб, 1885 с. 217.

95 Полное собрание русских летописей, Т. 5: Псковская 2-я и Софийская 1-я летописи, СПб, 1851, с. 14.

96 Полное собрание русских летописей, Т. 7: Летопись по Воскресенскому списку, СПб, 1856, с. 215-216. 
ji kilo maištas, po kurio šią kunigaikštystę pradèjo valdyti lietuviai ${ }^{97}$. Briansko užvaldymas leido Algirdui tiesiogiai sustiprinti savo karini potencialą. Veikiausiai iš karto ši kunigaikštystė buvo perduota valdyti sūnui Dimitrijui, nors jis kaip Briansko kunigaikštis pirmą kartą paminètas tik 1371 m. ${ }^{98}$, o $1372 \mathrm{~m}$. dar buvo tituluojamas ir Drucko kunigaikščiu ${ }^{99}$. Iki to laiko apie Dimitrijaus Algirdaičio aktyvumą žinių nèra, tačiau didelè tikimybè, kad jis dalyvavo Algirdo žygiuose.

Užėmus Brianską, Algirdo veiksmai Rusioje pasidare intensyvesni, nors apie jų mastą sunku ką nors tiksliau pasakyti. $1359 \mathrm{~m}$. Algirdas toliau stiprino LDK pozicijas Rusioje. Jis pats nužygiavo ị Smolensko žemę ir užėmė Mstislavlį, be to, tais pačiais metais savo sūnų Andrių pasiuntè kariauti ị Rževą, kurị šis ir paėmè. Tik kitais metais didysis kunigaikštis apsilankė Rževe ${ }^{100}$. Algirdo aktyvi veikla, orientuota ị pietus, subrandino atvirą konfliktą su Aukso orda. Viso to padarinys - Mèlynujų Vandenų mūšis. Nors šaltiniai apie ji pateikia nedaug duomenų, aišku, jog pagal savo mastą ir organizacinius užmojus tai buvo vienas didžiausių Algirdo surengtų žygių. Metraštyje pateikiama tokia informacija: Algirdas nugalèjo totorius, vedamus Kutlubugo, Kačibejjaus ir Dimitrijaus, tačiau dèl to, jog jie buvo tiesioginiai Podolès valdovai, ị šią žemę buvo pasiųsti Karijotaičiai, kurie ten ir ịsitvirtino ${ }^{101}$. Karijotaičiai i Podolę atvyko Algirdui padedant (galbūt netiesiogiai), pasistate joje pilis ir nustojo totoriams mokèti duokles ${ }^{102}$. Veikiausiai Karijotaičių žygis į Podolę buvo Algirdo žygio tąsa. Tai rodo jo mastas: Algirdas, patraukęs prieš totorius, ne tik pasitelkẻ brolį Karijotą su sūnumis, bet ir gerokai išplètė visą kariuomenę. Karijotaičiai anksčiau veikè Voluinejje ${ }^{103}$, taigi žygio metu galejo būti pasitelkti ir šios žemès kariai. Kyla klausimas - ar jame dalyvavo Liubartas, kuris tuo metu valdė Voluinę? Jokiuose kituose Algirdo žygiuose jis nedalyvavo, nors buvo itrauktas ị Algirdo politiką, kas akivaizdžiausiai matyti analizuojant dinastijos diplomatiją. Su Mèlynujų Vandenų mūšio padariniais siejamas ir Kijevo ku-

97 Полное собрание русских летописей, Т. 10: Летописный сборник, именуемый Патриаршею или Никоновскою летописью. СПб, 1885 с. 228.

98 Kuczyński S. M., Ziemie czernihowsko-siewierskie pod rządami Litwy, Warszawa, 1936, s. $149-151$.

99 Tęgowski J., Pierwsze pokolenia Giedyminowiczów, Poznań-Wrocław, 1999, s. 74.

100 Полное собрание русских летописей, Т. 10: Летописный сборник, именуемый Патриаршею или Никоновскою летописью. СПб, 1885 с. 231.

101 Полное собрание русских летописей, Т. 35: Летописи белорусско-литовские, М., 1980, c. 66.

102 Полное собрание русских летописей, Т.17. Западнорусские летописи. СПб, 1907, стб. 99-100.

${ }^{103}$ Plg.: Paszkiewicz H., Polityka ruska Kazimierza Wielkiego, Warszawa, 1925, s. 229. 
nigaikščio pakeitimas, kai Algirdas „pasodino“ savo sūnų Vladimirą ${ }^{104}$. Taigi žygyje neišvengiamai turejjo dalyvauti ir Algirdaičiai (kas visiškai natūralu). Negalima pamiršti ir sudėtingų LDK įsitvirtinimo procesų Černigovo ir Severènųžemèse, prasidẻjusių po Mèlynųjų Vandenų mūšio, kai Algirdas atskirose kunigaikštystėse ịkurdino savo sūnus ${ }^{105}$. Galiausiai taip pat galima prisiminti ir A. Kučinsko spejjimą, jog veikiausiai šiame žygyje dalyvavęs ir Kęstutis, kurio pozicija prie Kauno, aprašoma Vygando Marburgiečio kronikoje, atrodo išties keista ir nelabai atitinkanti tikrovę ${ }^{106}$. Tai leidžia suvokti, kokiu mastu galèjo būti organizuojamos Lietuvos Didžiosios Kunigaikštystès pajėgos vadovaujant didžiajam kunigaikščiui, kaip buvo telkiami dinastijos nariai.

Pasitikint A. Kučinsko spejjimu, jog būtent Mèlynųjų Vandenų žygio metu kryžiuočiai pirmąkart šturmavo Kauną, galima susidaryti vaizdą, kaip buvo telkiamas valstybès karinis potencialas. Net ir rengiant dideli žygi pasienio gynybos organizavimas buvo itin svarbus. Naujai piliai ginti buvo palikta didelè igula, vadovaujama Kęstučio sūnaus Vaidoto ${ }^{107}$. Užtrukus apsiausčiai, prie Kauno su savo būriais atsirado dar du „karaliai“. Jeigu atmestume prielaidą ${ }^{108}$, jog tai buvo Algirdas ir Kęstutis (pasak A. Kučinsko, taip ir reikètų padaryti), galima būtų spèti iš titulų, jog šiai apgultai piliai padėti atžygiavo taip pat dinastijai priklausantys kunigaikščiai, turbūt su ịgulomis laukę kitose pasienio pilyse. Tai, jog reali pagalba nebuvo suteikta, tik dar kartą patvirtina, kad disponuojama karinè jèga nebuvo didelè ir jos nebūtų užtekę atviram mūšiui laimèti. Galiausiai ir pati kariuomenès, kurią sudarè bajorai ir „smerdai“ („smyrdens“), kokybè buvo labai abejotina ${ }^{109}$. Čia reikètų atkreipti dẻmesị ir ị Vygando Marburgiečio kronikos specifiką. Galbūt jos tikslumas nukentejo ir rengiant vertimą? Gal originale nurodoma, kad ten buvo Kęstučio ir Algirdo sūnūs, o ne jie patys? Tai taip pat šį tą paaiškintų.

Dèl sustiprejusių pozicijų Algirdas tapo akivaizdžiu dinastijos lyderiu. Jis galëjo aktyviai veikti Rytuose ne tik tiesiogiai, nes daugėjant galimybių i š ši pro-

104 Полное собрание русских летописей, Т. 2: Ипатьевская летопись, СПб, 1843, с. 350 (žinutė iš Gustino metraščio, kurio tekstas buvo įdètas į ši tomą kaip priedas).

${ }^{105}$ Kuczyński S. M., Ziemie czernihowsko - siewierskie pod rządami Litwy, Warszawa, 1936, s. 149-194.

${ }^{106}$ Kučinskas A., Kęstutis, Vilnius, 1988, p. 70-73.

${ }^{107}$ Die Chronik Wigands von Marburg, hrsg. T. Hirsch // Scriptores rerum Prussicarum: Die Geschichtsquellen der preussischen, Bd. 2, Leipzig, 1863, s. 537.

${ }^{108}$ Hermani de Wartberge, Chronicon Livoniae, hrsg. E. Streblke // Scriptores rerum Prussicarum: Die Geschichtsquellen der preussischen, Bd. 2, Leipzig, 1863, s. 81.

${ }^{109}$ Die Chronik Wigands von Marburg, hrsg. T. Hirsch // Scriptores rerum Prussicarum: Die Geschichtsquellen der preussischen, Bd. 2, Leipzig, 1863, s. 533. 
cesą buvo įtraukiami ir kiti dinastijos nariai, visų pirma sūnūs. Tiesa, Andrius Algirdaitis kariauti pradejo anksti ir iki pat Algirdo mirties buvo aktyvus. Vis dèlto Algirdas galejo remtis ir kitais sūnumis, pirmiausia Dimitrijumi ir Vladimiru, kitais dinastijos nariais. Tai geriausiai atsiskleidè 1368-1372 m. konflikto su Maskva metu. $1368 \mathrm{~m}$. Andrius Algirdaitis surengè savarankišką žygi ${ }^{110}$, o vẻliau veikiausiai dalyvavo ir tèvo vadovaujamame žygyje i Maskvą kartu su Kęstučiu ir jo sūnumi Vytautu bei visais Algirdo sūnumis. Metraštyje taip pat pabrèžiama, jog šiame žygyje dalyvavo ir „visi Lietuvos kunigaikščiai“111, išskiriant Tverés kunigaikštį Michailą ir Smolensko pajëgas ${ }^{112}$. Ne mažesnio masto buvo ir kiti du Algirdo žygiai į Maskvą, surengti $1370^{113}$ ir 1372 metais $^{114}$. Tačiau Algirdo kare su Maskva dinastijos pozicija labiausiai išsiskyrė 1371 m., kai Tverès kunigaikščiui Michailui buvo suteikta parama. Algirdas pats šiame žygyje nedalyvavo, Lietuvos pajėgoms vadovavo Kęstutis, su kuriuo buvo sūnus Vytautas, Andrius ir Dimitrijus Algirdaičiai ${ }^{115}$. Būtent jie suteikė pagalbą Michailui. Šis pavyzdys aiškiai rodo, jog Algirdas, organizuodamas karo veiksmus, nebūtinai pats turëjo juose dalyvauti, o galëjo tam panaudoti kitus dinastijos narius, pirmiausia brolius ir sūnus. Mažai tikètina, kad Kęstutis tokiame žygyje būtų dalyvavęs savo iniciatyva ir be Algirdo žinios.

Vargu ar teiginys, kad Algirdas buvo pavedęs Liubartui vadovauti kovoms su Voluine, yra visiškai teisingas. Šiuo atveju tikètina prielaida, kad būtent Liubartas, kurio valdos buvo Lenkijos kaimynysteje, pirmasis turejo reaguoti i Lenkijos karines kampanijas ir telkti pajègas joms atremti, todèl aktyviai dalyvavo karo veiksmuose. Reikètų pasakyti, jog Liubartas gana pasyviai dalyvavo karo žygiuose kitomis kryptimis. Pagrindinis jo rūpestis buvo išsaugoti savo pozicijas Voluinejje, dẻl kurios nuolat vyko konfliktai su Lenkija.

1349 m. Lenkijos karalius Kazimieras su didele kariuomene užpuolė Rusią. Liubartas patyrè pralaimėjimą, o $1350 \mathrm{~m}$. Lietuvos ir Rusios kunigaikščiai puolè Lenkiją ${ }^{116}$. Kas tie Lietuvos ir Rusios kunigaikščiai, neaišku, tačiau tur-

110 Полное собрание русских летописей, Т.18: Летопись Симеоновская, СПб, 1913, с. 107.

111 Полное собрание русских летописей, Т.15: Летописный сборник, именуемый Тверской летописью, СПб, 1863, стб. 429.

112 Полное собрание русских летописей, Т.23: Ермолинская летопись. СПб, 1910, с. 115.

113 Полное собрание русских летописей, Т.25. Московский летописный свод конца XV века, М.-Л., 1949, с. 186.

114 Полное собрание русских летописей, Т.4: Новгородская 4-я и Псковская 1-я летописи. СПб, 1848, с. 69.

115 Полное собрание русских летописей, Т.16: Летописный сборник, именуемый летописью Авраамки, СПб, 1889, стб. 95.

${ }^{116}$ Joannis de Czarnkow, Chronicon Polonorum, opr. J. Szlachtowski // Monumenta Poloniae historica. Pomniki dziejowe Polski, T. 2, Lwów, 1872 s. 629-630. 
būt ne tik Kęstutis ir Liubartas, bet ir kiti dinastijos nariai. 1351 m. Kęstutis ir toliau aktyviai kovojo su Lenkija ${ }^{117}$. Dèsninga ir tai, kad būtent čia aktyviai pradejjo reikštis Narimanto sūnus Jurgis, kuris $1351 \mathrm{~m}$. gynè Belzo pilį ${ }^{118}$. Vis dèlto dinastijos integracija ị karo procesus geriausiai atsiskleide $1352 \mathrm{~m} .{ }^{119}$ Kazimiero III ir Gediminaičių sutartyje. Ją sudarant dalyvavo Jaunutis, Kęstutis, Liubartas, Jurgis Narimantaitis ir Jurgis Karijotaitis ${ }^{120}$. Tiketina, jog tai aktyviausi karo dalyviai. Dèl Kęstučio, Liubarto ir Jurgio Narimantaičio nèra abejonių. Reikia pridurti, jog vėlesniais metais Voluinëje aktyviai veikè ir Jurgis Karijotaitis, taigi, kad jis dalyvavo šiame kare, taip pat tikètina. Jaunučio dalyvavimas sudarant sutartị su Kazimieru iš dalies paaiškintų, ką reiškia lietuvių ir Rusios kunigaikščiai, minimi Janko iš Čarnkovo kronikoje. Sunkiai paaiškinama, kokia šiame kare buvo Algirdo, Karijoto ir Patriko (jeigu čia turimas omenyje Gardino kunigaikštis, kuris nebuvo dinastijos narys $)^{121}$ pozicija, tačiau dalyvavusieji garantavo ir jų bei jų vaikų vardu, kad sutarties bus laikomasi ${ }^{122}$. Veikiausiai šie kunigaikščiai taip pat epizodiškai dalyvavo karo veiksmuose, bet sudarant sutartị negalejo atvykti. Vis dèlto Algirdas negalejo palikti Voluinès vien Liubarto žinioje, todèl bent jau paskutiniais metais ten veikè ir jo sūnus Teodoras, kuris valde Ratno kunigaikštystę (1377 m. Hermanas Vartbergè mini „Koddere, filius Algerden“, kuris kartu su Algirdo broliu Liubartu pasidavė Vengrijos karaliui Liudvikui) ${ }^{123}$.

Panaši situacija buvo ir kovų su Vokiečių ordinu fronte. Nors dažniausiai Kęstutis turejjo rengti žygius vienas, neretai buvo pasitelkiamos platesnès pajègos, dalyvaujant ir didžiajam kunigaikščiui Algirdui, taip pat kitiems dinastijos nariams. Jau pirmasis didelis žygis i Prūsiją po Strẻvos mūšio $1352 \mathrm{~m}$. rodo, kad dinastijos ištekliai buvo plačiai naudojami. Vygandas Marburgietis sako, kad vadovavo lietuvių karaliai, veikiausiai turèdamas omenyje Algirdą ir Kęstutị, kadangi jie abu dalyvavo žygyje. Tačiau mažai tikètina, jog tik šie

117 Spominki Sochaczewskie, oprac. A. Bielowski // Monumenta Poloniae historica. Pomniki dziejowe Polski, T. 3, Lwów, 1878 s. 120.

${ }^{118}$ Prochaska A., Od Mendoga do Jagietly // Litwa i Ruś : miesięcznik ilustrowany poświęcony kulturze, dziejom, krajoznawstwu i ludoznawstwu, T.4, z.1, Wilno, 1912, s. 44.

${ }^{119}$ Paszkiewicz H., Polityka ruska Kazimierza Wielkiego, Warszawa, 1925, s. 160.

${ }^{120}$ Акты, относящиеся к истории Западной России, Т. 1: 1340-1506 г2., Санктпетербургъ, 1846, c. 1-2.

${ }^{121}$ Pakštalis A., Traku vaivadijos geneze // Darbai ir dienos, T. 44, Kaunas, 2005, p. 51-52.

122 Акты, относящиеся к истории Западной России, Т. 1: 1340-1506 г2., Санктпетербургъ, 1846, c. 1-2.

${ }^{123}$ Hermani de Wartberge, Chronicon Livoniae, hrsg. E. Streblke // Scriptores rerum Prussicarum: Die Geschichtsquellen der preussischen, Bd. 2, Leipzig, 1863, s. 115. 
du Gediminaičiai žygiavo ị Prūsiją, o ir šaltiniai neleidžia to teigti. Visų pirma ịsiveržusi kariuomenè buvo padalyta mažiausiai ị 5 dalis. Dviem iš jų vadovavo Kęstutis ir Algirdas, vèliau visos dalys turëjo susijungti. Vygandas Marburgietis taip pat nurodo, jog žygyje dalyvavo ir „Smolensko karalius“, kuris vadovavo mažiausiai 500 vyru būriui ir turejo prisijungti prie Algirdo Labguvoje. Dar labiau padidindamas aprašymo prieštaravimus, kronikininkas tikslina, kad šis „karalius“ buvo Kęstučio brolio sūnus ${ }^{124}$. Galima tik numanyti, jog tai ne vienas iš Algirdaičių, nes jis būtų susijęs su pačiu Algirdu, kuris dalyvavo žygyje. Abejotina ir tai, jog tai galëjęs būti Kęstučio sūnus Patrikas (viena iš nuomonių istoriografijoje) ar Smolensko kunigaikštis Ivanas Aleksandrovičius ${ }^{125}$. Galiausiai pats Smolensko įvardijimas tampa problema, nes kronikoje nurodoma „rex de Smalentz“126. Todèl labiau tikètina, kad čia bus isivèlusi klaida ir aprašyme minimas ne Smolensko, o kokios nors kitos vietovès kunigaikštis, kilęs iš Gediminaičių dinastijos (galbūt valdęs Slonimą ar Svisločę), nors Janas Dlugošas taip pat kalba apie Smolenską ${ }^{127}$. Vygandas Marburgietis mini ir vélesnius Algirdo ir Kęstučio bendrus žygius ị Prūsiją - 1361, 1365, 1370 ir 1376 metu $^{128}$, nors abejotina, ar pirmajame žygyje Algirdas dalyvavo ${ }^{129}$. Veikiausiai ir čia neišvengta klaidos, juolab jog nurodytas per mažas karių skaičius (500 vyrų), kad būtų galima kalbėti apie didesnį žygi, kokiuose paprastai dalyvaudavo didysis kunigaikštis, o Algirdas tarp kunigaikščiu minimas paskutinis ${ }^{130}$. Tiesa, J. Dlugošas hierarchiją pataiso, tačiau pats įvykių aprašymas lieka toks pat $^{131}$. Šio žygio metu Kęstutis pateko į nelaisvę. Kronikoje aprašomas Patriko pabėgimas, tačiau neužsimenama apie Algirdo veiksmus. Visa tai verčia manyti, jog Algirdas išties nedalyvavo paskutiniame žygyje. Išskirtiniu laikytinas ir 1365 m. žygis, kuriame dalyvavo Algirdas, Kęstutis, Patrikas ir Aleksandras.

${ }^{124}$ Die Chronik Wigands von Marburg, hrsg. T. Hirsch // Scriptores rerum Prussicarum: Die Geschichtsquellen der preussischen, Bd. 2, Leipzig, 1863, s. 516-519.

125 Trimonienė R., Gudmantas K., Paaiškinimai // Vygandas Marburgietis, Naujoji Prūsijos kronika, Vilnius, 1998, p. 278.

${ }^{126}$ Die Chronik Wigands von Marburg, hrsg. T. Hirsch // Scriptores rerum Prussicarum: Die Geschichtsquellen der preussischen, Bd. 2, Leipzig, 1863, s. 518.

${ }^{127}$ Joannis Dlugossii Senioris Canonici Cracoviensis, Opera omnia. Historiae Polonicae libri XII, T. 3, Krakow, 1876, s. 247.

${ }^{128}$ Die Chronik Wigands von Marburg, hrsg. T. Hirsch // Scriptores rerum Prussicarum: Die Geschichtsquellen der preussischen, Bd. 2, Leipzig, 1863, s. 527; 549; 563; 567.

${ }^{129}$ Kučinskas A., Kęstutis, Vilnius, 1988, p. 63.

${ }^{130}$ Die Chronik Wigands von Marburg, hrsg. T. Hirsch // Scriptores rerum Prussicarum: Die Geschichtsquellen der preussischen, Bd. 2, Leipzig, 1863, s. 527-528.

131 Joannis Dlugossii Senioris Canonici Cracoviensis, Opera omnia. Historiae Polonicae libri XII, T. 3, Krakow, 1876, s. 285-286. 
Tais metais Kęstutis dalyvavo dviejuose žygiuose ị Prūsiją: pirmasis buvo nedidelis, o vėlesnis, akivaizdžiai geriau parengtas, surengtas konkrečiam tikslui pasiekti ${ }^{132}$. Minimas šio žygio dalyvis kunigaikštis Aleksandras veikiausiai buvo Karijoto sūnus ${ }^{133}$, kuris jame galejo dalyvauti kaip Naugarduko kunigaikštis, nes Karijotas mire maždaug 1365 m. ${ }^{134}$ Tiesa, negalima pamiršti, kad tuo metu tarp Gediminaičiu galèjo būti dar vienas Aleksandras - Narimanto sūnus, minimas XIV a. ketvirtajame, o gal ir penktajame dešimtmetyje kaip veikiantis Didžiajame Naugarde ${ }^{135}$ (jo likimas nežinomas). Janas Tengovskis (Tęgowski) tokia galimybe abejoja, tačiau taip pat pamini kaip galimą variantą ${ }^{136}$.

Algirdas ir Kęstutis nuosekliai bendradarbiavo ir Livonijoje. Galbūt reikètų pridurti, jog dažniau čia iniciatyvos imdavosi pats Algirdas. Tik paskutiniame dešimtmetyje Algirdas Livonijai pradejo skirti palyginti mažiau dėmesio ir iniciatyvą perèmė Kęstutis. Tai veikiausiai sietina su Livonijos interesais, kurie buvo nukreipti ne tik i Lietuvą, bet ir i Rusią ${ }^{137}$. Hermano Vartbergès kronikoje pirmaisiais Algirdo valdymo dešimtmečiais lietuvių žygių i Livoniją vadas dažniausiai ịvardijamas kaip „karalius“, taigi kariuomenès vadai ir jos organizatoriai šaltiniuose lieka anonimiški. Tačiau kad Algirdas dalyvavo šiuose žygiuose kartu su Kęstučiu - akivaizdu.

1345 m. Algirdas, kaip sutariama istoriografijoje, įsiveržė į Žiemgalą. Nurodoma tik tai, kad karalius surinko didelę kariuomenę ${ }^{138}$. Turint omenyje Algirdo ir Kęstučio bendradarbiavimą, veikiausiai žygyje turejo dalyvauti ir pastarasis, nors negalima atmesti ir kitų brolių dalyvavimo galimybės. Bartalomėjaus Hionekès kronikoje aprašant ši žygị daug dèmesio skiriama ir Rusios pajëgoms (nurodoma, kad dalyvavo 2000 karių), ${ }^{139}$ kas rodo, jog kariuomenè tikrai buvo gausi ir nevienalytė. $1360 \mathrm{~m}$. lietuviams įsiveržus ị Livoniją, ji buvo padalyta ị dvi dalis ${ }^{140}$. Tokios analogijos matomos Algirdo ir Kęstučio

${ }^{132}$ Die Chronik Wigands von Marburg, hrsg. T. Hirsch // Scriptores rerum Prussicarum: Die Geschichtsquellen der preussischen, Bd. 2, Leipzig, 1863, s. 549.

${ }^{133}$ Batūra R., Lietuva tautų kovoje prieš Aukso Ordą: Nuo Batu antplūdžio iki mūšsio prie Mèlynųjų Vandenu, Vilnius, 1975, p. 266-267.

134 Tęgowski J., Pierwsze pokolenia Giedyminowiczów, Poznań-Wrocław, 1999, s. 164-167.

${ }^{135}$ Новгородская первая летопись старшего и младшего извода, М.-Л., 1950, с. 362.

136 Tęgowski J., Pierwsze pokolenia Giedyminowiczów, Poznań-Wrocław, 1999, s. 28.

${ }^{137}$ Varakauskas R., Lietuvos ir Livonijos santykiai XIII-XVI a., Vilnius, 1982, p. 255-269.

${ }^{138}$ Hermani de Wartberge, Chronicon Livoniae, hrsg. E. Streblke // Scriptores rerum Prussicarum: Die Geschichtsquellen der preussischen, Bd. 2, Leipzig, 1863, s. 72.

${ }^{139}$ Die jüngere livländische reimchronik des Bartholomäus Hoeneke, 1315-1348, Leipzig, 1872, p. 31.

${ }^{140}$ Hermani de Wartberge, Chronicon Livoniae, hrsg. E. Streblke // Scriptores rerum Prussicarum: Die Geschichtsquellen der preussischen, Bd. 2, Leipzig, 1863, s. 80. 
žygiuose į Prūsiją. Šiuo atveju lyginimas suteikia gana daug informacijos.

Kęstučio karinis potencialas Livonijoje pradèjo ryškèti tik XIV a. aštuntajame dešimtmetyje, kai Algirdas pats nebedalyvavo šiame regione rengiamuose žygiuose. Tačiau Kęstutis nebuvo vienas, čia dažnai reiškèsi ir Algirdaičiai. 1373 m. Skirgaila, o 1374 ir 1375 m. Andrius Algirdaitis puole Daugpili ${ }^{141}$. Tuo pat metu šiose kovose pradeda ryškèti ir Kęstučio figūra: 1375 m. jis su trimis Algirdo sūnumis, Smolensko „karaliumi“ ir Polocko kunigaikščiu Andriumi Algirdaičiu ịsiveržè į Livoniją, 1376 m. puolè Mintaujos ir Dobelès pilis, panašiu metu Andrius Algirdaitis siaube Rositès pilies apylinkes, nors neatrodo, jog šie žygiai buvo suderinti, nes Andrius i Livoniją įsiveržè veikiausiai Kęstučiui iš jos jau pasitraukus ${ }^{142}$.

Vis dèlto Lietuvos Didžiojoje Kunigaikštystejje pradèta konstruoti hierarchinè valdymo ir karo veiksmų organizavimo sistema Gedimino valdymo laikotarpiu suiro dèl po Algirdo mirties elito sluoksniuose atsiradusios itampos. Pirmiausia minètini Algirdo sūnų ir galimų paveldètojų nesutarimai, pradedant Jogailos ir Andriaus konfliktu. Patraukęs ị savo pusę brolius (Algirdo ir Marijos Vitebskietès sūnus) ir tolimesnius giminaičius, Andrius Algirdaitis susilpnino Jogailos karini potencialą ${ }^{143}$. Antras didelis dinastijos vidaus konfliktas ịsižiebė tarp Jogailos ir Kęstučio. Galima prisiminti, jog jis kilo būtent dèl susitarimų su Vokiečių ordinu ir karinio LDK potencialo perskirstymo ${ }^{144}$.

\section{APIBENDRINAMOSIOS PASTABOS}

Apibendrinant nagrinètą medžiagą vietoj išvadų vertètų pateikti keletą pastabų. Stokojant atitinkamų šaltinių i klausimus dėl XIII-XIV a. sandūroje Gedimino giminès ir ankstyvujų jos kartų (įskaitant ir Gedimino kartą) dalyvavimo rengiant karo veiksmus sunku išsamiai atsakyti. Galima tik pažymèti, kad šiuo laikotarpiu stengtasi pasikliauti artimiausiais giminaičiais, tačiau karo veiksmai dar nebuvo tapę aiškia valstybės interesų gynimo forma. Dinastijos narių veikla vis dar primena XIII a. laikotarpio veiksmus, kai buvo remiamasi asmeniniais interesais ir kariaunomis. Gedimino valdymo metu padètis pradejo keistis: dinastijos atstovai buvo įtraukiami ị karo veiksmų organizavimą, ir šios prievolès susipynè su administracinėmis jų funkci-

${ }^{141}$ Ten pat, p. 103-104.

${ }^{142}$ Ten pat, p. 104-106.

${ }^{143}$ Batūra R., Lietuvos karo vadai ir kariai 1380 m. Kulikovo müšyje // Karo archyvas, T. 19, Vilnius, 2004, p. 84-147.

${ }^{144}$ Kodex dyplomatyczny Litwy. Wydany z rękopismów $w$ archiwum tajnem $w$ królewcu zachowanych, wyd. E. Raczyński, Wrocław, 1845, s. 53-56. 
jomis. Tai leidžia išskirti keletą LDK sričių, kurios buvo valdomos vadovaujantis hierarchiniais dinastijos principais. Didžiojo kunigaikščio galią šiuo laikotarpiu pirmiausia liudija jo sutelktos didžiausios karinès pajėgos. Jas papildydavo kiti dinastijos nariai savo kunigaikštysčių pavaldiniais. Karinė galia didžiajam kunigaikščiui užtikrino dinastijos lyderio poziciją. Tačiau ši sistema veikẻ tik tam tikrą laiką - iki Gedimino sūnų mirties. Mirus Algirdui, dinastijos hierarchiniai principai jau buvo pažeisti, o Jogaila nebegalejo disponuoti visu karininiu potencialu taip, kaip Algirdas. Todèl karinio potencialo organizavimo principai turejo keistis. Vis dèlto administracinés ir karinès funkcijos liko neatskirtos ilgiau nei išsilaikè susiformavusios karinès sritys.

Iteikta $2010 \mathrm{~m}$. balandžio $7 \mathrm{~d}$. 


\title{
SUMMARY
}

\section{THE ROLE OF GEDIMINAS DYNASTY IN ORGANIZING MILITARY ACTIONS WITHIN THE GRAND DUCHY OF LITHUANIA IN THE 14TH CENTURY}

\author{
Vytis Jankauskas, Vytautas Magnus University
}

Seeking to better describe the development of the Grand Duchy of Lithuania from the end of the 13th century to the 15th century, it is very important to pay a proper attention to the dynasty, its functioning and hierarchical relations inherent in it. This problem is complex and multifaceted since sources of the period under discussion provide only hints or allusions and indirect data. Because of that, the attempt to find out what the relations of the dynasty members within the structure were, are still more complicated. In this study attempts will be made to evaluate the role of the dynasty as a structure in organizing military actions from the end of the 13th century to the 15 th century.

Analyzing the role of the Gediminas dynasty in organizing military actions, this article makes use of different-nature sources, but primarily of the narrations of the discussed period about the then military actions. Other sources covering international relations are also used as supplementary information where it is possible.

Generalizing the above presented material, it is necessary to make several remarks: at the turn of the 13 th -14 th centuries, the aspect of the organization of military actions by Gediminas family and its former generations in the light of the dynasty is complex to resolve because of the lack of sources. It should only be pointed out that during this period, every attempt was made to approach closest relatives, yet military actions hardly manifested themselves as a form of defending state interests; therefore, actions of the dynasty members still reminded of the 13th century actions of militants where the emphasis was on personal interests and militancy. During the ruling of Gediminas, the situation started to change and the dynastic aspect of the organization of military actions substantially intertwined with the adminis- 
trative functions of the dynasty thus permitting to single out several areas of the Grand Lithuanian Duchy which were organized under the principles of a hierarchical dynasty. During this period, the power of the Grand Duke was primarily manifested by consolidating huge military forces augmented by other dynasty members from their duchies. The military power guaranteed the Grand Duke the position of the leader in the dynasty. However, this system functioned for only a definite period of time, until the sons of Gediminas passed away. As early as after the demise of Algirdas, the hierarchical principles of the dynasty were violated, so that Jogaila, in contrast to Algirdas, could not have this military potential at his complete disposal. Consequently, military potential organization principles had to be rearranged. In spite of that, the intertwining of administrative and military functions survived longer than the formed military areas. 